\title{
Geographic variation in the macrofaunal associates of pelagic Sargassum and some biogeographic implications
}

\author{
Allan W. Stoner ${ }^{1}$ and Holly S. Greening ${ }^{2}$ \\ ${ }^{1}$ Center for Energy and Environment Research, University of Puerto Rico, Mayagüez, Puerto Rico 00708, \\ ${ }^{2}$ Institute of Ecology University of Georgia, Athens, Georgia 30602, USA
}

\begin{abstract}
The macrofauna associated with individually collected clumps of pelagic Sargassum was influenced strongly by the location of sampling. Algae collected in the Sargasso Sea carried more species with lower dominance and higher evenness and variation in abundance than algae collected in the Gulf Stream. Gulf Stream samples were dominated by the shrimp Latreutes fucorum (67.8\%) with little compositional variation whereas the gastropod Litiopa melanostoma was the most abundant but weakly dominant species (25.1\%) in the Sargasso Sea. Generally, species endemic to pelagic Sargassum species were most abundant in the Sargasso Sea while numerous temporary associates were found in the Gulf Stream. Numbers of individuals and species increased with the weight of algal clumps but clump size had little effect on the species composition of algal associates. Variation in species composition and trophic organization of macrofaunal associates with geographic region and with algal age were related to differences in the epiphytization of the algae. Because of the dissimilarity in algal associates of the Gulf Stream and Sargasso Sea, the influx of littoral fauna from the West Indies to the Sargasso Sea is probably very slow and the present forms may have evolved in that water mass.
\end{abstract}

\section{INTRODUCTION}

The organisms associated with pelagic Sargassum form a discrete biotic community representing at least 11 phyla and over 100 animal species, many of which are endemic to the floating habitat (see review by Butler et al., 1983). The community has been described in general (e. g. Hedgpeth, 1957; Morris and Mogelberg, 1973) and for specific types of organisms such as epibiota (Conover and Sieburth, 1964; Carpenter, 1970; Carpenter and Cox, 1974; Ryland, 1974), motile invertebrates (Timmerman, 1932; Weis, 1968; Fine, 1970), and fishes (Adams, 1960; Dooley, 1972; Bortone et al., 1977); however, the individuality of Sargassum clumps has rarely been examined. Exceptions are studies conducted by Fine (1970) and Butler et al. (1983). A series of over 200 samples collected near Bermuda shows important seasonal variation in the motile associates of Sargassum weed (Butler et al, 1983); however, the observed seasonality may be confounded by variation related to the ages of individual clumps. A clear succession of bacteria and other sessile epibiota has been associated with the age and result- ant antibacterial activity of the algal substratum (Conover and Sieburth, 1964; Ryland, 1974). Because many of the motile invertebrates associated with Sargassum are dependent upon epibiotic foods, algal age probably has an important effect on motile associates as well.

Geographic variation in Sargassum associates is even less well known and understood. Best documented variation is for epiphytes (Conover and Sieburth, 1964; Carpenter, 1970; Smith et al., 1973; Carpenter and Cox, 1974), but studies noting geographic variation for motile invertebrates (Fine, 1970) and fishes (Dooley, 1972; Bortone et al., 1977, comparing Dooley, 1972) are plagued by lack of simultaneous sampling in different geographic regions and low sample numbers. Recognizing the potential significance of variation in Sargassum associates between the Gulf Stream and Sargasso Sea, Fine (1970) suggested simultaneous sampling to distinguish spatial and temporal variation in the Sargassum community.

In this report, we use a large number of individually examined samples to document striking differences between Sargassum communities from the Gulf Stream 
and Sargasso Sea; all samples were collected within a two-week period and the effects of Sargassum clump size and age are examined. The results are discussed in light of known surface circulation in the northwest Atlantic Ocean and botanical literature on pelagic Sargassum and its epiflora.

\section{MATERIALS AND METHODS}

Six stations in the northwest Atlantic Ocean were sampled during R/V 'Westward' cruise W-58 in June and July, 1981. Gulf Stream stations were located at the west or north wall of the current as indicated by bathythermograph profile (i. e. just east of the position where the $15^{\circ} \mathrm{C}$ isotherm reached $200 \mathrm{~m}$ depth); 2 sites were sampled (Fig. 1). Four Sargasso Sea stations were sampled, well to the east and south of the Gulf Stream and where noticeable concentrations of Sargassum weed occurred. Surface water chemistry was examined at 4 of the 6 stations (Table 1). Water temperature was measured with a simple bucket thermometer and as part of routine hydrocasts, surface salinity was determined with a Grundy model $6230 \mathrm{~N}$ salinometer, dissolved oxygen concentration was measured with standard Winkler titration, and nutrient concentrations were measured with standard spectrophotometric methods as described by Strickland and Parsons (1972).

From the deck of R/V 'Westward', individual clumps of Sargassum were collected with a long-handled dip net (0.5 mm mesh). Each algal clump was submerged and vigorously shaken in freshwater to loosen motile fauna. The alga was identified to species and measured for displacemant volume in a large graduated cylinder. Later, displacement volumes were converted

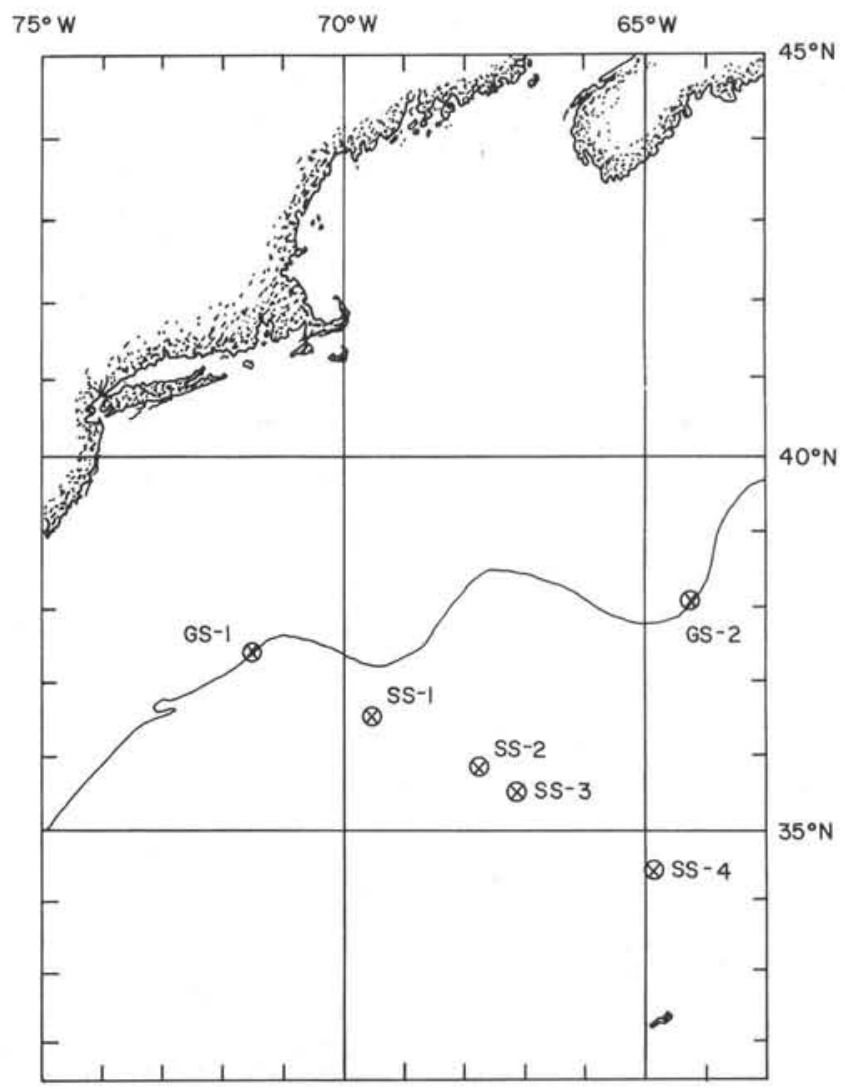

Fig. 1. Collecting sites in Gulf Stream (GS) and Sargasso Sea (SS). Line running through Gulf Stream sites: position of Gulf Stream north wall as shown by the US National Weather Service on 24 June 1981 and confirmed by bathythermograph at GS-1 and GS-2

to wet weight values using constants determined for Sargassum natans and S. fluitans, the 2 species collected. Relative age of the clump was recorded as young, middle or old, determined on the basis of

Table 1. Positions, temperatures, and water chemistry at 6 stations sampled for Sargassum weed on R/V 'Westward' cruise W-58. bd: concentration below the level of determination

\begin{tabular}{|c|c|c|c|c|c|c|c|}
\hline Station & $\begin{array}{c}\text { Date } \\
(1981)\end{array}$ & Position & $\begin{array}{c}\text { Temperature } \\
\left({ }^{\circ} \mathrm{C}\right)\end{array}$ & $\begin{array}{c}\text { Salinity } \\
(\% 0)\end{array}$ & $\begin{array}{l}\text { Dissolved } \\
\left(\mathrm{ml} \mathrm{1}^{-1}\right)\end{array}$ & $\begin{array}{c}\text { Phosphates } \\
\left(\mu \mathrm{M} \mathrm{l}^{-1}\right)\end{array}$ & $\begin{array}{l}\text { Silicates } \\
\left(\mu \mathrm{M}^{-1}\right)\end{array}$ \\
\hline GS-1 & 21 Jun & $\begin{array}{l}37^{\circ} 25^{\prime} \mathrm{N} \\
71^{\circ} 30^{\prime} \mathrm{W}\end{array}$ & 27.9 & 37.1 & 5.06 & bd & bd \\
\hline $\mathrm{SS}-1$ & 22 Jun & $\begin{array}{l}36^{\circ} 29^{\prime} \mathrm{N} \\
69^{\circ} 28^{\prime} \mathrm{W}\end{array}$ & 25.6 & & & & \\
\hline SS -2 & 23 Jun & $\begin{array}{l}35^{\circ} 42^{\prime} \mathrm{N} \\
67^{\circ} 48^{\prime} \mathrm{W}\end{array}$ & 25.4 & & (No data) & & \\
\hline SS -3 & 24 Jun & $\begin{array}{l}35^{\circ} 26^{\prime} \mathrm{N} \\
67^{\circ} 08^{\prime} \mathrm{W}\end{array}$ & 25.9 & 36.6 & 5.22 & bd & 1.3 \\
\hline SS -4 & $1 \mathrm{Jul}$ & $\begin{array}{l}34^{\circ} 26^{\prime} \mathrm{N} \\
64^{\circ} 58^{\prime} \mathrm{W}\end{array}$ & 25.3 & 36.4 & 5.47 & 0.16 & 1.1 \\
\hline GS-2 & $3 \mathrm{Jul}$ & $\begin{array}{l}38^{\circ} 05^{\prime} \mathrm{N} \\
64^{\circ} 02^{\prime} \mathrm{W}\end{array}$ & 27.5 & 36.1 & 5.58 & bd & 1.9 \\
\hline
\end{tabular}


epiphytization and color of the alga. Clumps designated as 'young' were those with bright yellow or yellow-green coloration and few to no epizoans or epiphytes. 'Old' clumps were those with dark coloration, brittle dark brown inner branches, and epizoans or epiphytes covering most of the algal surface area. 'Middle-aged' clumps were intermediate in character. Admittedly, age of Sargassum clumps is a continuous function rather than discrete; however, to date there is no good way to age Sargassum and the aging method described provided the relative values adequate for this study.

The macrofauna collected in the freshwater rinse were extracted on a Nitex screen with $0.5 \mathrm{~mm}$ openings and preserved in ethanol. No motile macrofauna remained attached to Sargassum clumps rinsed in freshwater. In the laboratory, all macrofauna were identified to species, measured for total length, and counted. Exceptions were polychaete worms which were not measured and fishes which were measured for standard length rather than total length.

For comparison of community composition between stations, Sorensen's quotient of similarity and the percent of similarity indices (Southwood, 1966) were calculated for each station pair. The possible effects of
Sargassum clump weight on number of individuals and number of species were tested using analysis of variance and least squares linear regression. Differences in the abundance of numerically important species between Gulf Stream and Sargasso Sea samples were tested with Student's t-test.

\section{RESULTS}

A total of 78 individual clumps of Sargassum weed (36 S. fluitans and 42 S. natans) were collected at the 6 stations, 38 at the Gulf Stream sites (GS) and 40 at the Sargasso Sea sites (SS), yielding 1788 macrofaunal individuals in 6 phyla and 23 species (Table 2). With all stations combined, the shrimp Latreutes fucorum comprised $45.3 \%$ of the total number of individuals collected, and the 6 most abundant species made up over $80 \%$ of the total. When examined separately, however, fauna from the 6 stations show high similarity (91.9) between Gulf Stream stations coupled with low similarity among Sargasso Sea stations and low similarity between Gulf Stream and Sargasso Sea stations (Table 3).

Using individual stations as replicates, Student's

Table 2. Motile macrofauna associated with Sargassum clumps from Gulf Stream and Sargasso Sea. Numbers of individuals collected and percent of total collection (in parentheses). GS = Gulf Stream catch significantly larger than Sargasso Sea catch. SS $=$ Sargasso Sea catch significantly larger. $\varnothing=$ no significant difference (Student's t-test $_{i}{ }^{*}=p<.05, \cdots=p<.01, \cdots=p$ $<.001)$. Trophic groups are based on determination made by Butler et al. (1983). See Table 4 for description

\begin{tabular}{|c|c|c|c|c|c|c|c|c|c|}
\hline \multirow[b]{2}{*}{1} & \multirow{2}{*}{$\begin{array}{c}\text { Rank species } \\
\text { Latreutes fucorum }\end{array}$} & \multirow{2}{*}{$\begin{array}{c}\begin{array}{c}\text { Trophic } \\
\text { group }\end{array} \\
5\end{array}$} & \multirow{2}{*}{ t-test } & \multicolumn{2}{|c|}{$\begin{array}{c}\text { Gulf Stream } \\
\text { stations }(n=38)\end{array}$} & \multicolumn{2}{|c|}{$\begin{array}{c}\text { Sargasso Sea } \\
\text { stations }(n=40)\end{array}$} & \multicolumn{2}{|c|}{$\begin{array}{l}\text { All stations } \\
(\mathrm{n}=78)\end{array}$} \\
\hline & & & & 610 & $(67.8)$ & 200 & $(22.5)$ & 810 & (45.3) \\
\hline 2 & Litiopa melanostoma & 5 & $\mathrm{SS} \cdots$ & 8 & $(0.9)$ & 223 & (25.1) & 231 & (12.9) \\
\hline 3 & Bagatus minutus & 2 & $\varnothing$ & 90 & $(10.0)$ & 77 & $(8.7)$ & 167 & $(9.3)$ \\
\hline 4 & Planes minutus & 5 & ss $\cdots$ & & & 105 & $(11.8)$ & 105 & $(5.8)$ \\
\hline 5 & Sunampithoe pelagica & 2 & ss $\cdots$ & & & 94 & (10.6) & 94 & (5.3) \\
\hline 6 & Gnescioceros sargassicola & 3 & SS & 20 & $(2.2)$ & 65 & $(7.4)$ & 85 & $(4.8)$ \\
\hline 7 & Platynereis dumerilli & 5 & $\varnothing$ & 33 & $(3.7)$ & 33 & $(3.7)$ & 66 & $(3.7)$ \\
\hline 8 & Leander tenuicornis & 5 & GS* & 52 & (5.8) & 14 & (1.6) & 66 & $(3.7)$ \\
\hline 9 & Portunus sayi & 5 & GS $\cdots$ & 41 & $(4.6)$ & 1 & $(0.1)$ & 42 & (2.3) \\
\hline 10 & Hoploplana grubei & 3 & ss $\cdots$ & & & 23 & $(2.6)$ & 23 & (1.3) \\
\hline 11 & Monacanthus hispidus & 6 & GS $*$ & 20 & $(2.2)$ & 2 & $(0.2)$ & 22 & (1.2) \\
\hline 12 & Hemiaegina minuta & 2 & $\varnothing$ & 12 & (1.3) & 9 & $(1.0)$ & 21 & $(1.2)$ \\
\hline 13 & Anoplodactylus petiolatus & 4 & $\varnothing$ & 5 & $(0.6)$ & 13 & (1.5) & 18 & $(1.0)$ \\
\hline 14 & Histrio histrio & 6 & SS* & 1 & $(0.1)$ & 8 & $(0.9)$ & 9 & $(0.5)$ \\
\hline 15 & Corambella depressa & 4 & & 3 & $(0.3)$ & 4 & $(0.5)$ & 7 & $(0.4)$ \\
\hline 16 & Luconacia incerta & 2 & & & & 5 & $(0.6)$ & 5 & $(0.3)$ \\
\hline 17 & Doto pygmaea & 4 & & 2 & $(0.2)$ & 3 & $(0.3)$ & 5 & $(0.3)$ \\
\hline 18 & Biancolina brassicacephala & 2 & & & & 3 & $(0.3)$ & 3 & $(0.2)$ \\
\hline 19 & Scyllaea pelagica & 4 & & & & 3 & $(0.3)$ & 3 & $(0.2)$ \\
\hline 20 & Hippolyte coerulenscens & 5 & & & & 2 & $(0.2)$ & 2 & $(0.1)$ \\
\hline 21 & Syngnathus pelagicus & 6 & & 2 & $(0.2)$ & & & 2 & $(0.1)$ \\
\hline 22 & Abudefduf saxatilis & 6 & & 1 & $(0.1)$ & & & 1 & $(0.05)$ \\
\hline & Diodon hystrix & 6 & & & & 1 & $(0.1)$ & 1 & $(0.05)$ \\
\hline \multirow{2}{*}{\multicolumn{2}{|c|}{$\begin{array}{l}\text { Number individuals } \\
\text { Number species }\end{array}$}} & & & \multicolumn{2}{|c|}{900} & \multicolumn{2}{|c|}{888} & \multicolumn{2}{|c|}{1788} \\
\hline & & & & \multicolumn{2}{|c|}{15} & \multicolumn{2}{|c|}{21} & \multicolumn{2}{|c|}{23} \\
\hline
\end{tabular}


Table 3. Between-station similarity. Percentage of similarity $[\% \mathrm{~S}=\Sigma \min (\mathrm{a}, \mathrm{b} \ldots \mathrm{x})]$ in lower half. Sorenson's quotient of similarity $(\mathrm{QS}=\mathrm{a}+\mathrm{b}, \mathrm{j}=$ total no. of species in $\mathrm{A}$ and $\mathrm{B}, \mathrm{a}$ $=$ no. of species in $\mathrm{A}, \mathrm{b}=$ no. of species in $\mathrm{B}$ ) in upper half.

(From Southwood, 1966)

\begin{tabular}{|lcccccc|}
\hline & GS-1 & SS-1 & SS-2 & SS-3 & SS-4 & GS-2 \\
\hline GS-1 & & 1.27 & 1.38 & 1.33 & 1.58 & 1.20 \\
SS-1 & 48.8 & & 1.15 & 1.24 & 1.36 & 1.29 \\
SS -2 & 22.4 & 68.7 & & 1.21 & 1.42 & 1.27 \\
SS -3 & 64.3 & 67.1 & 46.8 & & 1.44 & 1.29 \\
SS -4 & 19.0 & 50.3 & 41.6 & 34.8 & & 1.64 \\
GS-2 & 91.9 & 51.8 & 28.9 & 71.2 & 19.9 & \\
\hline
\end{tabular}

Table 4. Trophic organization of macrofauna as a function of locality, habitat size, and Sargassum age. Trophic types from Butler et al. (1983): 1 = planktivores (none were collected), 2 $=$ small omnivores which consume Sargassum, detritus, and sessile fauna, $3=$ small browsers which consume detritus, bryozoans, and harpacticoids, $4=$ small carnivores which feed on sessile fauna, 5 = large omnivores which consume a wide variety of sessile and motile plant and animal material, $6=$ large carnivores which consume motile fauna (see Table 2 ). Values are percentages of individuals

\begin{tabular}{|lrrrrr|}
\hline \multicolumn{1}{c}{ Habitat } & \multicolumn{5}{c|}{ Trophic type } \\
& 2 & 3 & 4 & 5 & 6 \\
\hline Location & & & & & \\
$\quad$ Gulf Stream & 11.3 & 2.2 & 1.1 & 82.8 & 2.6 \\
$\quad$ Sargasso Sea & 21.1 & 10.0 & 2.6 & 65.0 & 1.2 \\
$\quad$ Clump size & & & & & \\
$\quad$ Small & 17.3 & 7.7 & 1.6 & 71.9 & 1.5 \\
$\quad$ Medium & 15.3 & 7.1 & 2.0 & 74.0 & 1.6 \\
$\quad$ Large & 18.3 & 2.0 & 1.8 & 75.3 & 2.6 \\
$\quad$ Clump age & & & & & \\
$\quad$ Young & 18.4 & 7.2 & 0.5 & 71.5 & 2.4 \\
$\quad$ Middle & 16.8 & 6.7 & 2.3 & 72.2 & 2.0 \\
$\quad$ Old & 11.6 & 3.6 & 0.6 & 82.0 & 2.2 \\
\hline
\end{tabular}

Table 5. Summary stastistics for linear regressions of number of individuals and numbers of species versus Sargassum clump weight

\begin{tabular}{|lcccc|}
\hline Geographic area & $\mathrm{r}$ & $\mathrm{n}$ & $\mathrm{F}$ & $\mathrm{P}$ \\
\hline \multicolumn{5}{c}{ Number of individuals } \\
Gulf Stream & 0.614 & 38 & 21.12 & .001 \\
Sargasso Sea & 0.343 & 40 & 5.06 & .05 \\
All stations & 0.488 & 78 & 23.48 & .001 \\
& Number of species & \\
Gulf Stream & 0.597 & 38 & 19.36 & .001 \\
Sargasso Sea & 0.357 & 40 & 5.57 & .05 \\
All stations & 0.455 & 78 & 19.55 & .001 \\
\hline
\end{tabular}

t-test showed significant differences in the numerical importance of individual species in the 2 oceanographic areas (Table 2). Gulf Stream macrofauna were heavily dominated by the shrimp Latreutes fucorum (67.8\% of individuals). Sargasso Sea samples showed a more even distribution of species, with the gastropod Litiopa melanostoma making up $25.1 \%$ of the total count, followed in numerical importance by L. fucorum $(22.5 \%)$. Six species were significantly more numerous on Sargasso Sea clumps than on Gulf Stream samples, three of which were totally absent from the Gulf Stream. Four species were more abundant on Gulf Stream samples, but none of these were exclusively found there. With nearly identical numbers of individuals collected in the 2 geographic areas, the difference in the number of species between Gulf Stream and Sargasso Sea sites (15 versus 21 species) is a fair estimate.

Using the trophic groups identified by Butler et al. (1983), both Gulf Stream and Sargasso Sea macrofaunal assemblages were dominated by large omnivores; however, Sargasso Sea samples yielded fewer individuals in this group and more small omnivores which consume primarily sessile prey organisms (Table 4). Gulf Stream samples also yielded more large carnivores (mostly fishes) than Sargasso Seam samples.

Sargassum species had little influence on macrofaunal assemblages. The exception was Litiopa melanostoma which was significantly more abundant on $S$. natans than on $S$. fluitans $(20.2 \%$ versus $3.3 \%$ of the total count) $\left(\mathrm{x}^{2}=98.25, \mathrm{p}<.01\right)$. Otherwise, the 2 Sargassum species carried very similar faunas. Of the 23 species collected, 21 were found on $S$. fluitans, 22 on $S$. natans. For subsequent analyses, Sargassum species were considered together, but geographic regions were examined separately.

Number of individuals collected on an algal clump was a function of clump weight when all stations were combined (ANOVA, p < .001) or when Gulf Stream ( $\mathrm{p}$ $<.001$ ) and Sargasso Sea samples $(\mathrm{p}<.05)$ were considered separately (Table 5). Although the correlation coefficients (r) were significant and the regression equations for Gulf Stream and Sargasso Sea samples are very similar, the equations account for a relatively small percentage of variation in numbers of macrofauna collected.

As with the number of individuals, the number of species found on an algal clump increased with clump weight for all stations examined collectively (ANOVA, $\mathrm{p}<.001)$, for fauna from the Gulf Stream ( $\mathrm{p}<.001)$, and for Sargasso Sea samples $(\mathrm{p}<.05$; Table 5). Because of poor fit of points to the simple linear regressions, equations for Gulf Stream and Sargasso Sea samples cannot be differentiated; however, it is clear that Sargasso Sea algae carried more species than Gulf Stream clumps as discussed earlier.

To examine the effects of clump size on species 
Table 6. Composition of fauna associated with Sargassum clumps of 3 different size classes. $\mathrm{S}=9$ to $40 \mathrm{~g}$ wet weight, $\mathrm{M}=41$ to $100 \mathrm{~g}, \mathrm{~L}=>100 \mathrm{~g}$. Values are numbers of individuals collected and percentages of the total (parentheses)

\begin{tabular}{|c|c|c|c|c|c|c|}
\hline \multirow[t]{2}{*}{ Species } & \multicolumn{3}{|c|}{ Gulf Stream } & \multicolumn{3}{|c|}{ Sargasso Sea } \\
\hline & $S(n=20)$ & $M(n=13)$ & $L(n=5)$ & $S(n=18)$ & $M(n=17)$ & $L(n=5)$ \\
\hline Latreutes fucorum & $184(72.1)$ & $199(60.9)$ & $227(71.4)$ & $69(21.2)$ & $63(18.4)$ & $68(30.9)$ \\
\hline Litiopa melanostoma & & $6(1.8)$ & $2(0.6)$ & $83(25.5)$ & $118(34.5)$ & $22(10.0)$ \\
\hline Bagatus minutus & $29(11.4)$ & $47(14.4)$ & $14(4,4)$ & $19 \quad(5.8)$ & $31 \quad(9.1)$ & $27(12.3)$ \\
\hline Planes minutus & & & & $22(6.7)$ & $45(13.2)$ & $38(17.3)$ \\
\hline Sunampithoe pelagica & & & & $47(14.4)$ & $15(4.4)$ & $32(14.5)$ \\
\hline Gnescioceros sargassicola & & $15(4.6)$ & $5 \quad(1.6)$ & $40(12.3)$ & $23(6.7)$ & $2(0.9)$ \\
\hline Platynereis dumerilli & $7 \quad(2.7)$ & $20(6.1)$ & $6 \quad(1.9)$ & $18 \quad(5.5)$ & $13(3.8)$ & $2 \quad(0.9)$ \\
\hline Leander tenuicornis & $7(2.7)$ & $11(3.4)$ & $34(10.7)$ & $4 \quad(1.2)$ & $5(1.5)$ & $5 \quad(2.3)$ \\
\hline Portunus sayi & $15 \quad(5.9)$ & $14 \quad(4.3)$ & $12(3.8)$ & & $1(0.3)$ & \\
\hline Hoploplana grubei & & & & $10(3.1)$ & $10(2.9)$ & $3(1.4)$ \\
\hline Monacanthus hispidus & $5 \quad(2.0)$ & $6 \quad(1.8)$ & $9 \quad(2.8)$ & & $1 \quad(0.3)$ & $1 \quad(0.5)$ \\
\hline Hemiaegina minuta & $5 \quad(2.0)$ & $5 \quad(1.5)$ & $2(0.6)$ & $2(0.6)$ & $3(0.9)$ & $4 \quad(1.8)$ \\
\hline Anoplodactylus petiolatus & $2(0.8)$ & $1 \quad(0.3)$ & $2(0.6)$ & $1(0.3)$ & $7(2.0)$ & $5 \quad(2.3)$ \\
\hline $\begin{array}{l}\text { Histrio histrio } \\
\text { Petrotas }\end{array}$ & $1(0.4)$ & & & $2(0.6)$ & $2(0.6)$ & $4 \quad(1.8)$ \\
\hline Corambella depressa & & $3(0.9)$ & & $2(0.6)$ & $2(0.6)$ & \\
\hline Luconacia incerta & & & & & & $5 \quad(2.3)$ \\
\hline Doto pygmaea & & & $2(0.6)$ & $3(0.9)$ & & \\
\hline Biancolina brassicacephala & & & & $1(0.3)$ & $1(0.3)$ & $1 \quad(0.5)$ \\
\hline Scyllaea pelagica & & & & $2(0.6)$ & $1(0.3)$ & \\
\hline Hippolyte coerulenscens & & & & $1 \quad(0.3)$ & & $1 \quad(0.5)$ \\
\hline Syngnathus pelagicus & & & $2(0.6)$ & & & \\
\hline Abudefduf saxatilis & & $1(0.3)$ & & & & \\
\hline Diodon hystrix & & & & & $1(0.3)$ & \\
\hline Number individuals & 255 & 327 & 318 & 326 & 342 & 220 \\
\hline
\end{tabular}

composition, clumps were categorized as small ( 9 to 40 g wet weight), medium (41 to $100 \mathrm{~g})$, and large ( $>100$ g). Species composition on Gulf Stream algae was relatively stable over clump size, although total number of species increased from 9 to 13 (Table 6). Of the numerically important species, the shrimp Leander tenuicornis increased in relative abundance from small to large clumps, and Bagatus minutus and the polychaete Platynereis dumerilli were most abundant on medium-sized clumps. Few other consistent increases or decreases were observed. More dramatic changes with clump size occurred on the Sargasso Sea. Although the evenness of species abundance and species richness was consistently higher in the Sargasso Sea than in the Gulf Stream, dominance switched from Litiopa melanostoma to $L$. fucorum with clump size in the Sargasso Sea (Table 6). Except for a slight transition from small omnivores and carnivores to larger species, the trophic organization of Sargassum associates was relatively stable over clump size (Table 4).

The effects of apparent clump age were more dramatic than the effects of clump size. Latreutes fucorum showed a major decrease in relative abundance with algal age in the Sargasso Sea (from 41.2 to $17.9 \%$ ) and an increase with age in the Gulf Stream (54.3 to $74.1 \%$ ) (Tables 7 and 8). Litiopa melanostoma showed a large increase in relative abundance with age in the Sargasso Sea, while Gulf Stream samples contained few gastropods. An obvious transition from small to large omnivores occurred with increasing age of Sargassum clumps (Table 4), while the relative abundances of carnivores remained relatively stable. Browsers declined slightly in numerical abundance in the oldest clumps. Because of differences in the numbers of individuals collected in different age classes, a comparison of numbers of species is not valid.

Certain of the invertebrates, including Latreutes fucorum, Litiopa melanostoma, Bagatus minutus, and Leander tenuicornis, were sufficiently large and abundant to test for regional differences in size (Table 9); however, none of these species showed differences in length-frequency between the Gulf Stream and Sargasso Sea (Student's t-test, $\mathrm{p}>.10$ ). Similarly, no differences in size were found in fauna from algal habitats of different age or size.

\section{DISCUSSION}

Associations between fauna and pelagic Sargassum, whether obligatory or facultative, provide numerous advantages to the animals. Although few species directly consume the relatively unpalatable brown 
Table 7. Motile macrofauna associated with Sargassum clumps of 3 different ages from Gulf Stream. Values are numbers of individuals collected and percentages of the total (in parentheses)

\begin{tabular}{|c|c|c|c|}
\hline \multirow[t]{2}{*}{ Rank species } & \multicolumn{3}{|c|}{ Age of algae } \\
\hline & $\begin{array}{l}\text { Young } \\
(\mathrm{n}=5)\end{array}$ & $\begin{array}{l}\text { Middle } \\
(\mathrm{n}=28)\end{array}$ & $\begin{array}{l}\text { Old } \\
(n=5)\end{array}$ \\
\hline 1 Latreutes fucorum & $19(54.3)$ & $571(68.1)$ & $20(74.1)$ \\
\hline 2 Bagatus minutus & $6(17.1)$ & $83 \quad(9.9)$ & 1 (3.7) \\
\hline 3 Leander tenuicornis & $2(5.7)$ & $49 \quad(5.9)$ & $1(3.7)$ \\
\hline 4 Portunus sayi & $1 \quad(2.9)$ & $39 \quad(4.7)$ & $1(3.7)$ \\
\hline 5 Platynereis dumerilli & $4(11.4)$ & $26(3.1)$ & $3(11.1)$ \\
\hline 6 Gnescioceros sargassicola & $2(5.7)$ & $18 \quad(2.1)$ & \\
\hline 7 Monacanthus hispidus & $1(2.9)$ & $18 \quad(2.1)$ & $1 \quad(3.7)$ \\
\hline 8 Hemiaegina minuta & & $12(1.5)$ & \\
\hline 9 Litiopa melanostoma & & $8 \quad(1.0)$ & \\
\hline 10 Anoplodactylus petiolatus & & $5(0.6)$ & \\
\hline 11 Corambella depressa & & $3(0.4)$ & \\
\hline 12 Doto pygmaea & & $2(0.2)$ & \\
\hline 13 Syngnathus pelagicus & & $2(0.2)$ & \\
\hline 14 Abudefduf saxatilis & & $1(0.1)$ & \\
\hline 15 Histrio histrio & & $1 \quad(0.1)$ & \\
\hline Number individuals & 35 & 838 & 27 \\
\hline
\end{tabular}

algae, pelagic Sargassum species have been shown to release large amounts of dissolved organic material (Hansen, 1977) which is utilized by heterotrophic bacteria. Additionally, the concentration of phosphates in the water surrounding a Sargassum clump may be as much as 2 to 3 times the concentration outside the clumps (Sutcliffe et al., 1963; Culliney, 1970). The result is an environment of relatively enriched organic productivity for autotrophs as well as consumers. The Sargassum habitat also provides a source of attachment sites for sessile and motile organisms in an otherwise open-water environment, and the substratum probably protects its associates from pelagic predators and mechanical disturbance by waves.

The number, kind, and species richness of macrofaunal associates, however, appears to be highly variable. Although a weak correlation was found between numbers of associates and the size of Sargassum clumps, this relation is expected and has been documented before (Fine, 1970; Butler et al., 1983). Species composition was relatively stable over clump size and increasing species richness is most likely a simple stochastic function of increasing numbers of individuals. More interesting was the geographic variation in Sargassum associates found in this study which may be explained by the circulation of the North Atlantic and information taken from the botanical literature on Sargassum and its epiphytes.

Given the anticyclonic circulation of the North Atlantic subtropical gyre system which encompasses the Sargasso Sea, Sargassum in the Gulf Stream is
Table 8. Motile macrofauna associated with Sargassum clumps of 3 different ages from Sargasso Sea. Values are numbers of individuals collected and percentages of the total (in parentheses)

\begin{tabular}{|c|c|c|c|}
\hline \multirow[t]{2}{*}{ Rank species } & \multicolumn{3}{|c|}{ Age of algae } \\
\hline & $\begin{array}{l}\text { Young } \\
(n=6)\end{array}$ & $\begin{array}{l}\text { Middle } \\
(n=23)\end{array}$ & $\begin{array}{c}\text { Old } \\
(n=11)\end{array}$ \\
\hline 1 Litiopa melanostoma & $10(9.8)$ & $130(23.9)$ & $83(34.4)$ \\
\hline 2 Latreutes fucorum & $42(41.2)$ & $115(21.1)$ & $43(17.9)$ \\
\hline 3 Planes minutus & $10(9.8)$ & $67(12.3)$ & $28(11.6)$ \\
\hline 4 Sunampithoe pelagica & $15(14.7)$ & $52 \quad(9.5)$ & $27(11.2)$ \\
\hline 5 Bagatus minutus & $5 \quad(4.9)$ & $59(10.8)$ & $13(5.4)$ \\
\hline 6 Gnescioceros sargassicola & $7(6.8)$ & $53(9.7)$ & $5(2.1)$ \\
\hline 7 Platynereis dumerilli & $4 \quad(3.9)$ & $16 \quad(2.9)$ & $13(5.4)$ \\
\hline 8 Hoploplana grubei & $2(2.0)$ & 9 (1.6) & $12(5.0)$ \\
\hline 9 Leander tenuicornis & $4 \quad(3.9)$ & $7(1.3)$ & $3(1,3)$ \\
\hline 10 Anoplodactylus petiolatus & $1(1.0)$ & $11 \quad(2.0)$ & $1(0.4)$ \\
\hline 11 Hemiaegina minuta & & $3(0.6)$ & $6 \quad(2.5)$ \\
\hline 12 Histrio histrio & $2(2.0)$ & $5 \quad(0.9)$ & $1(0.4)$ \\
\hline 13 Luconacia incerta & & $5 \quad(0.9)$ & \\
\hline 14 Corambella depressa & & $4 \quad(0.7)$ & \\
\hline 15 Biancolina brassicacephala & & $2(0.4)$ & $1(0.4)$ \\
\hline 16 Doto pygmaea & & $2(0.4)$ & $1(0.4)$ \\
\hline 17 Scyllaea pelagica & & $2(0.4)$ & $1(0.4)$ \\
\hline 18 Hippolyte coerulescens & & & $2(0.8)$ \\
\hline 19 Monacanthus hispidus & & $2(0.4)$ & \\
\hline 20 Diodon hystrix & & & $1(0.4)$ \\
\hline 21 Portunus sayi & & $1 \quad(0.2)$ & \\
\hline Number individuals & 102 & 545 & 241 \\
\hline
\end{tabular}

moving from the West Indies, Caribbean Sea, and Gulf of Mexico to the North Atlantic. Based on morphological analyses, Winge (1923) and Parr (1939) believed that there was only small contribution of Sargassum from the West Indies and Gulf of Mexico to the Sargasso Sea. Parr stated that he could easily distinguish specimens of Sargassum collected in the Gulf of Mexico from those collected in the Sargasso Sea and that only a small percentage of the weed carried on the Gulf Stream reached the Sargasso Sea. He concluded that most of the Gulf Stream Sargassum was carried north where it died because of low temperatures, and that Sargasso Sea populations were propagated vegetatively in situ.

Although Parr's conclusions are difficult to prove, the biological (if not physical) distinctness of Sargassum communities in the Gulf Stream and Sargasso Sea is supported by findings in this analysis. Macrofaunal communities in the Gulf Stream showed lower species richness, more large species, and less variable species composition than communities in the Sargasso Sea, as well as major compositional differences. Similar to findings here, Fine (1970) noted the greater variation in Sargasso Sea communities than in the Gulf Stream and that the filefish Monacanthus hispidus was more abundant inshore. Bortone et al. (1977) found $M$. his- 
Table 9. Lengths $(\mathrm{mm})$ of selected invertebrates in Gulf Stream and Sargasso Sea. Values are means \pm S.D. Numbers in parentheses are numbers measured. No species showed significant differences among treatments (Student's t-test, p $>.10$ )

\begin{tabular}{|lcccc|}
\hline Habitat & Latreutes fucorum & Litiopa melanostoma & Bagatus minutus & Leander tenuicornis \\
\hline Gulf Stream & $9.25 \pm 2.33$ & $3.06 \pm 2.20$ & $3.79 \pm 1.36$ & $18.48 \pm 8.52$ \\
$(610)$ & $(8)$ & $(91)$ & $(50)$ \\
Sargasso Sea & $9.20 \pm 2.18$ & $3.16 \pm 1.27$ & $(223)$ \\
& $(200)$ & $(78)$ & $1.58 \pm 1.25$ & $(14)$ \\
\hline
\end{tabular}

pidus to make up $84.5 \%$ of the Sargassum associated ichthyofauna in the Gulf of Mexico while the Sargassum fish, Histrio histrio, was rarely encountered. The trend was also found in the Gulf Stream analyses of this study and it is clear that the filefish as well as other fish such as the damselfish Abudefduf saxatilis have nearshore origins and affinities. Also noticeably rare in the Sargasso Sea was the crab Portunus sayi, confirming a Gulf Stream-Sargasso Sea dichotomy noted by Fine (1970). None of these species are endemic to pelagic Sargassum. On the other hand, species believed to be endemic to the floating alga such as Planes minutus, Sunampithoe pelagica, Hoploplana grubei, Biancolina brassicacephala, and Scyllaea pelagica were found exclusively in the Sargasso Sea samples and only $1 \mathrm{H}$. histrio was collected in the Gulf Stream. Although the Gulf Stream and Florida Current carry large loads of Sargassum (Stoner, 1983), and the ancestors of the Sargasso Sea endemics may be littoral fauna of the West Indies as suggested by Timmermann (1932), the influx of closely-related West Indian fauna must be very slow and the present forms probably evolved in the Sargasso Sea. Decreasing significance of nearshore organisms on Sargassum with distance from North America was noted for fishes by Dooley (1972). Because of what we know about exchange of water and organisms between the continental slope, Gulf Stream and Sargasso Sea on frequently formed Gulf Stream rings (Ortner et al., 1979; Backus et al., 1981; Wiebe, 1982), however, the significance of the barrier between Gulf Stream and Sargasso Sea Sargassum populations (and communities) is probably less than that hypothesized by Parr (1939). On a least 1 occasion, Portunus sayi were observed as being very abundant in a warm ring of the Gulf Stream located in continental slope water at approximately $39^{\circ} \mathrm{N}$ latitude and $61^{\circ} \mathrm{W}$ longitude (Stoner, own observ.).

Whether or not differences between the Sargassum communities of the two water masses are related to lack of gene flow, certain ecological mechanisms are possibly important in structuring the communities in different regions. Several studies have shown regional differences in the abundance of sessile epibiota on Sargassum. Conover and Sieburth (1964) found epiphyte loads in the southern Sargasso Sea (below $30^{\circ} \mathrm{N}$ latitude) to be significantly lower than those in the north; they concluded that this was a result of higher antimicrobial activity by southern Sargassum populations. Also, examining respiration values, Smith et al. (1973) showed that epiphytes of Sargassum were a much more important part of the community in waters of the continental slope than in the Gulf Stream. This was confirmed by Carpenter (1970) and Carpenter and Cox (1974) who found that the blue-green epiphyte Dichothrix fucorum decreased in biomass from shelf water to the Gulf Stream to the Sargasso Sea. Disagreeing with Conover and Sieburth, they attributed the differential growth of epiphytes to regional differences in nutrient availability. Regardless of mechanism, differences in the epiphytization of Sargassum in the Gulf Stream and Sargasso Sea (Carpenter and Cox, 1974; own observ.) may very well explain some of the compositional differences in motile macrofauna. For example, the high percentage of Gulf Stream omnivores (Type 5 consumers) that utilize epiphytes and sessile invertebrates is most likely related to degree of epiphytization. Also, protection offered by heavy epiphytization in the Gulf Stream may aid in the survival of larger species found there. Sargasso Sea fauna included more small omnivores (Type 2) which consume Sargassum and detritus.

Age-related differences in Sargassum communities observed in this study may be explained in a manner similar to that used to explain geographic variation. Successional patterns of development in the sessile components of the Sargassum community have been examined (Conover and Sieburth, 1964; Ryland, 1974). Bacteria appear first, and are quickly followed by hydroids of great variety, then bryozoans, and finally blue-green, red, and green algae. Increases in the larger omnivores such as Latreutes fucorum and Litiopa melanostoma with Sargassum age would imply a trophic mechanism in succession of motile fauna, but experimental work is needed. Patterns could be related to a number of other biological mechanisms including differential reproductive strategies, predation, and competition. Nevertheless, because clump size appeared to have little influence on the composi- 
tion of macrofaunal associates, and because clump age and size were independent, age is the most important factor.

Sargassum associates are regulated by a complex set of factors including numerous elements of historic accident and biotic interaction. It is unknown whether successional patterns in sessile or motile epibiota are related to preparation of surfaces or habitats by early colonizers and/or a probabilistic pattern related to reproductive strategies. Associations are probably dependent upon where and when the algal clump was first colonized, its history of attachment to other clumps, and exchange between clumps in windrows or large mats which form under certain weather conditions. Influence by predators and potential competitors are probable, but unknown.

In conclusion, the macrofaunal associates of the Sargassum complex are strongly influenced by the age and geographic location of individual algal clumps which, in turn, are related to differences in epiphytization of the algae. Although numbers of individuals and species increased with the weight of algal clumps, Sargassum species and clump size had little effect on the species composition of associates. Geographic variation in species composition of the algal associates, however, corroborates Parr's (1939) idea that Sargassum from the Caribbean Sea and Gulf of Mexico is distinct from the Sargasso Sea population. The implied lack of influx from the West Indies suggests that the Sargasso Sea forms may have evolved in that water mass.

Acknowledgements. We gratefully acknowledge the assistance of Sea Semester students on RV 'Westward' cruise W-58 in collecting Sargassum samples and separating fauna. Taxonomic assistance was provided by K. D. Brady and G. L. Ray. G. Morrison and J. Gerritsen helped to improve the manuscript. Our work was supported by the Sea Education Association, Woods Hole, Massachusetts, operator of the R/V 'Westward', and the Center for Energy and Environment Research, Mayagüez, Puerto Rico.

\section{LITERATURE CITED}

Adams, J. A. (1960). A contribution to the biology and post larval development of the Sargassum fish, Histrio histrio (Linnaeus), with a discussion of the Sargassum complex. Bull. mar. Sci. Gulf Caribb. 10: 55-82

Backus, R. H., Flierl, G. R., Kester, D. R., Olson, D. B., Richardson, P. L., Vastano, A. C., Wiebe, P. H., Wormuth, J. H. (1981). Gulf Stream bold core rings: their physics, chemistry, and biology. Science, N. Y. 212: 1091-1100

Bortone, S. A., Hastings, P. M., Collard, S. B. (1977). The pelagic Sargassum ichthyofauna of the eastern Gulf of Mexico. Northeast Gulf Sci. 1: 60-67

Butler, J. N., Morris, B. F., Cadwallader, J., Stoner, A. W. (1983). Studies of Sargassum and the Sargassum community. Bermuda Biological Station, Spec. Publ. 22: 1-307.

Carpenter, E. J. (1970). Diatoms attached to floating Sargassum in the western Sargasso Sea. Phycologia 9: 271-274

Carpenter, E. J., Cox, J. L. (1974). Production of pelagic Sargassum and a blue-green epiphyte in the western Sargasso Sea. Limnol. Oceanogr. 19: 429-436

Conover, J. T., Sieburth, J. McN. (1964). Effect of Sargassum distribution on its epibiota and antibacterial activity. Botanica mar. 6: 147-157

Culliney, J. L. (1970). Measurements of reactive phosphorus associated with pelagic Sargassum in the northwest Sargasso Sea. Limnol. Oceanogr. 15: 304-306

Dooley, J. K. (1972). Fishes associated with the pelagic Sargassum complex, with a discussion of the Sargassum community. Contr. mar. Sci., Univ. Tex. 16: 1-32

Fine, M. L. (1970). Faunal variation on pelagic Sargassum. Mar. Biol. 7: 112-122

Hansen, R. B. (1977). Pelagic Sargassum community metabolism - carbon and nitrogen. J. exp. mar. Biol. Ecol. 29: 107-118

Hedgpeth, J. W. (1957). Marine biogeography. In: Hedgpeth, J. W. (ed.) Treatise on marine ecology and paleoecology, Vol. 1, Marine ecology. Geological Society of America. (Mem. geol. Soc. Am. 67)

Morris, B. F., Mogelberg, D. D. (1973). Identification manual to the pelagic Sargassum fauna. Bermuda Biological Station, Spec. Publ. 11: 1-63

Ortner, P. B., Hurlburt, E. M., Wiebe, P. H. (1979). Phytohydrography, Gulf Stream rings, and herbivore habitat contrasts. J. exp. mar. Biol. Ecol. 39: 101-124

Parr, A. E. (1939). Quantitative observations on the pelagic Sargassum vegetation of the western North Atlantic. Bull. Bingham oceanogr. Coll. 60: 1-94

Ryland, J. S. (1974). Observations on some epibionts of gulfweed, Sargassum natans (L. Meyen). J. exp. mar. Biol. Ecol. 14: 17-25

Southwood, T. R. E. (1966). Ecological methods, with particular reference to the study of insect populations. Methuen, London

Smith, K. L., Burns, K. A., Carpenter, E. J. (1973). Respiration of the pelagic Sargassum community. Deep Sea Res. 20: 213-217

Stoner, A. W. (1983). Pelagic Sargassum: evidence for a major decrease in biomass. Deep Sea Res. 30: 469-474

Strickland, J. D. H., Parsons, T. R. (1972). A practical handbook of seawater analysis, 2nd ed. Bull. Fish. Res. Bd Can. 167

Sutcliffe, W. H., Baylor, E. R., Menzel, D. W. (1963). Sea surface chemistry and Langmuir circulation. Deep Sea Res. 10: 233-243

Timmerman, G. (1932). Biogeographische Untersuchungen über die Lebensgemeinschaft des treibenden Golfkrautes. Z. Morphol. Ókol. Tiere 25: 288-335

Weis, J. S. (1968). Fauna associated with pelagic Sargassum in the Gulf stream. Am. Midl. Nat. 80: 554-558

Wiebe, P. H. (1982). Rings of the Gulf Stream. Scient. Am. 246: $60-70$

Winge, O. (1923). The Sargasso Sea, its boundaries and vegetation. Rep. Dan. oceanogr. Exped. 1908-1910. 3 (2): 1-34 